\title{
Spinal Metastasis as Presenting Feature of Follicular Type Thyroid Carcinoma: A Case Report and Review of the Literature
}

\author{
Spinal Metastazla Belirti Veren Folliküler Tip Tiroid Karsinomu: \\ Olgu Sunumu ve Literatür Taraması
}

\section{(D) Azmi Tufan1, (D Burak Eren¹, (D Abdurrahim Taş¹, (D) Neslihan Berker2, (D Özgür Yusuf Aktaş1, (D) İlker Güleç 1 , (D) Mustafa Safi Vatansever ${ }^{1}$, (D) Murat Karacan¹, (D) Günay Vahabova1, (D) Feyza Karagöz Güzey1}

${ }^{1}$ University of Health Sciences, İstanbul Bağcılar Training and Research Hospital, Clinic of Neurosurgery, İstanbul 2University of Health Sciences, İstanbul Bağcılar Training and Research Hospital, Clinic of Pathology, İstanbul

\section{Abstract}

Objective: Follicular type thyroid carcinoma (FTC) rarely presented with spinal metastasis. We aimed to report such a case and to review the literature.

Method: A 45 year old male with L2 metastasis of FTC was reported, and other 26 cases were found in literature. Characteristics of the patients and tumors were evaluated.

Results: Total 27 patients were $55.2 \pm 15$ years of age, and male/ female ratio was 12/15. Nineteen patients had paresis of extremities, 9 of them could not mobilize on admission. Total resection of the spinal tumor had been performed in 14 cases and subtotal resection in 5 . Radioactive iodine treatment had been added in 20 cases with or without other adjuvant treatment. Twenty-three patients had been followed for $43.7 \pm 53.2$ months. Only four of them died $214,66,36$ and 7 months after their presentations. Out of other 19 cases, 13 had been neurologically normal. Type of surgery (total resection versus others) the only factor affecting outcome. In the patients treated with total resection, outcome had been statistically better.

Conclusion: Spinal metastasis as initial finding is very rare in the patients with FTC. However, prognosis is quite well with total tumor resection and adjuvant treatment. This cancer type must be kept in mind for differential diagnosis and must be screened in the patients with spinal tumors.

Keywords: Differentiated thyroid carcinoma, follicular type thyroid carcinoma, spinal metastasis, spinal tumor

\section{Öz}

\begin{abstract}
Amaç: Folliküler tip tiroid karsinomu (FTK) nadiren spinal metastazla belirti verir. Böyle bir olgu sunmayı ve bu konuda literatür taramayı amaçladık.
\end{abstract}

Yöntem: Lomber 2 spinal metastazla belirti veren 45 yaşında erkek FTK olgusu sunuldu ve literatürde benzer 26 olgu bulundu. Tüm olguların özellikleri değerlendirildi.

Bulgular: Toplam 27 olgu 55,2 \pm 15 yaşındaydı (35-88 arasında, ortalama \pm SS) ve erkek/kadın oranı 12/15 idi. Başvuruda 19 olguda kol ve/veya bacaklarda güçsüzlük vardı ve 9'u mobilize olamıyordu. Spinal tümör 14 olguda total, 5 olguda subtotal çıkarıldı. Yirmi olguya radyoaktif iyot tedavisi eklendi. Olguların 23 'ü $3-214$ ay $(43,7 \pm 53,2$, ortalama \pm SS) süreyle izlenmişti, sadece 4 olgu başvurudan 214, 66, 36 ve 7 ay sonra ölmüştü. Halen sağ olan 19 olgunun 13'ü nörolojik olarak normaldi. Uygulanan cerrahi tipi (total çıkarmaya karşılık diğer cerrahi tipleri) son durumu etkileyen tek faktör olarak saptandı. Tümörü total çıkarılan hastalarda sondurum anlamlı olarak daha iyiydi.

Sonuç: Folliküler tip tiroid karsinomunun spinal metastazla belirti vermesi çok nadirdir. Ancak total tümör çıkarılması ve adjuvan tedaviyle prognoz iyidir. Spinal tümörlü hastalarda bu kanser tipi de ayrıcı tanıda akılda tutulmalı ve tarama testleri yapılmalıdır.

Anahtar kelimeler: Diferansiye tiroid karsinomu, folliküler tip tiroid karsinomu, spinal metastaz, spinal tümör

Address for Correspondence: Günay Vahabova, University of Health Sciences, İstanbul Bağcılar Training and Research Hospital, Clinic of Neurosurgery, İstanbul

E-mail: gunay_baghirova@yahoo.com ORCID ID: orcid.org/0000-0002-4942-9380 Received: 18.01.2019 Accepted: 18.01.2019

Cite this article as: Tufan A, Eren B, Taş A, Berker N, Aktaş ÖY, Güleç I, Vatansever MS, Karacan M, Vahabova G, Karagöz Güzey F. Spinal Metastasis as Presenting Feature of Follicular Type Thyroid Carcinoma: a Case Report and Review of the Literature. Bagcilar Med Bull 2019;4(1):1-9.

${ }^{\circledR}$ Copyright 2019 by the Health Sciences University, Bagcilar Training and Research Hospital Bagcilar Medical Bulletin published by Galenos Publishing House. 


\section{Introduction}

Differentiated thyroid cancers (DTC) contain papillary, follicular and Hurthle cell types. Follicular type thyroid cancer (FTC) is the second most frequent type of DTCs, and it is more inclined to metastasize to the bone than papillary type (1). This characteristic is probably due to that FTC usually spreads via blood, however, papillary type prefers lymphatic route for dissemination (2). There is bone involvement in $7-12 \%$ of the cases with FTC (3), and the most frequently involved region is spinal column (4). However, most of the spinal metastases occur in the late stage of the disease, and presentation of the disease with spinal metastasis is extremely rare during initial diagnosis.

We presented such a rare case who was admitted with lumbar spinal metastasis, and thyroid cancer was diagnosed after pathological evaluation of the spinal tumor. Also we reviewed the literature for presentation with spinal metastasis of FTC, and we evaluated the characteristics of the cases that we found.

\section{Case Report}

A 45 year-old male was admitted to our outpatient clinic with complaints of low back and severe left leg pain and numbness of left leg for 5 months. There was hypoesthesia on left L1 and L2 dermatomes on his physical examination. Muscle strength was full. Radiological examinations revealed an L2 vertebral body tumor. On lumbar computerized tomography (CT) examination, an osteolytic heterogeneous tumor involving left half of the L2 vertebral body extending into the left paravertebral muscles and into the left L1-2 and L2-3 neural foramens was seen (Figure 1). On lumbar magnetic resonance imaging (MRI), it was hypointense on T1-weighted images, and heterogeneous hypo- and hyperintense on T2-weighted images (Figure 2). The lesion was hypermethabolic on positron emission tomography (PET) CT, and there were also a hypermethabolic enhancement in the left thyroid lobe and mildly hypermethabolic bilateral multiple cervical lymph nodes.

A lumbar biopsy was performed and a carcinoma consistent with FTC was diagnosed (Figure 3a). It was decided to perform tumor resection and stabilization for lumbar tumor first because there was severe leg pain of the patient and instability of the lumbar spine, and also the tumor was the sole metastasis on the PET-CT. Total tumor resection and stabilization with interbody cage insertion and pedicle screw fixation was performed via posterior approach (Figure 4). There was not residual tumor on postoperative MRI.

Immunohistochemical investigations revealed that the tumor cells were positive for thyroglobuline, thyroid transcription factor 1 (TTF-1), Hector Battifora mesothelial cells 1 (HBME-1) and cytokeratin-19 (CK-19), and negative for calcitonin (Figure 3b-f). These findings verified the diagnosis of DTC.

Total thyroidectomy was performed by endocrine surgery team 10 days after our lumbar operation, and pathological

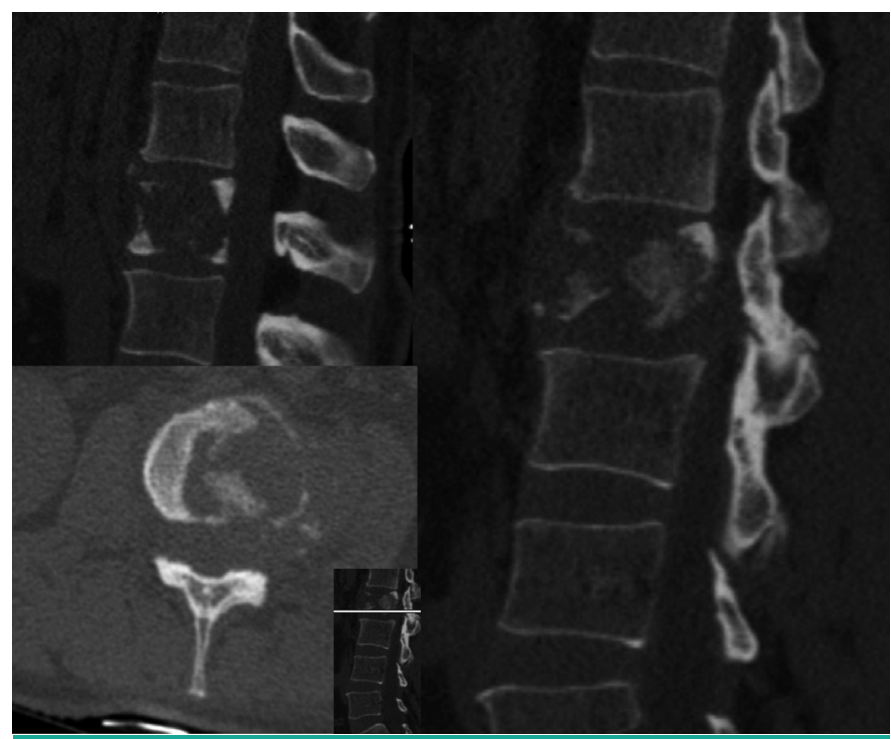

Figure 1. Sagittal and axial sections of the lumbar vertebral computerized tomography demonstrating lytic L2 vertebral tumor extending into the left paravertebral region and neural foramens

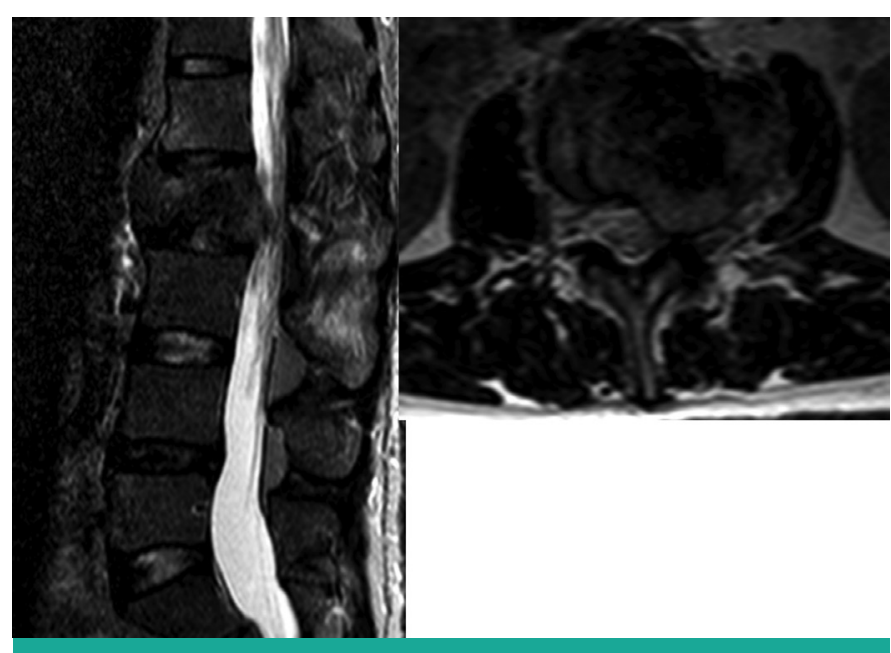

Figure 2. Sagittal and axial sections of the T2-wieghted lumbar spinal magnetic resonance imaging demonstrating heterogeneous hypo- and hyperintense tumor in the L2 vertebral body compressing the nerve roots 
examination revealed follicular type carcinoma. He was treated with iodine 131 ablation. His follow-up examinations were uneventful, and there was not recurrence or new metastasis 2 years later.

\section{Material and Methods}

Review of the literature: we reviewed the literature for spinal metastasis as presenting feature of FTC from Medline and Google Scholar. We found 28 such cases. However 2 cases were not introduced into the study because there was not adequate data in the articles $(5,6)$. The characteristics of total 27 cases including our one were evaluated $(1,2,4,7-24)$ (Table 1). Demographic characteristics, levels and numbers of the spinal metastases, neurological conditions, other metastases, treatment modalities, follow-up time, and outcome of the cases were recorded.

Outcome was accepted as good if the patient was neurologically normal or could mobilize without external support, and it was accepted as poor if the patient could not mobilize without support or was dead.

\section{Statistical Analysis}

For statistical analysis, chi-square test, Fisher exact test, and Student's t-tests were used, and $\mathrm{p}<0.05$ was accepted as significant.

\section{Results}

The patients were $55.2 \pm 15$ years of age (mean \pm SD, between 35 and 88 ), and male/female ratio was $12 / 15$. The most involved levels were thoracic and thoracolumbar segments. The involved vertebral levels in the patients were shown in the Table 2.

The lesion was intradural extramedullary (IDEM) in one case (20), and vertebral and/or epidural in the others. The IDEM tumor extended beyond 2 lumbar levels. In the others, only one vertebra was involved in 11 patients, 2 adjacent vertebrae in 5 , and 3 adjacent vertebrae in 7 were involved. Most of the patients had solitary vertebral metastases or multiple adjacent levels involvement. In

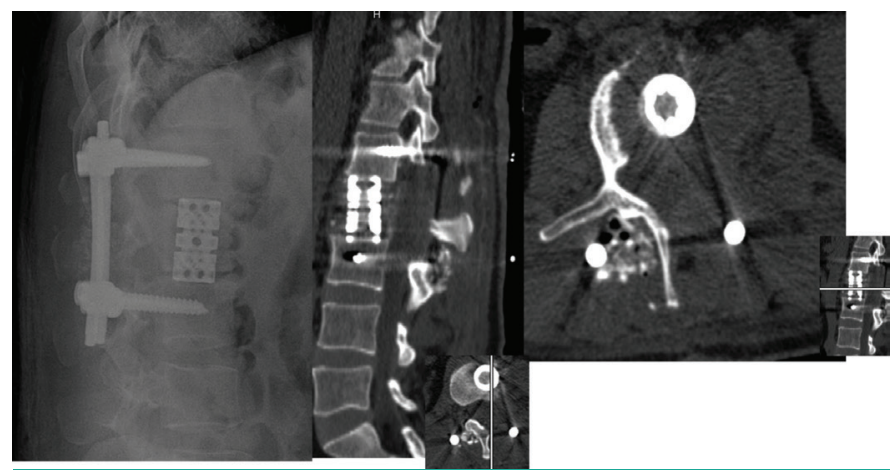

Figure 4. Lateral lumbar radiograph and sagittal and axial lumbar computerized tomography demonstrating total tumor resection and spinal stabilization with interbody cage and pedicle screws

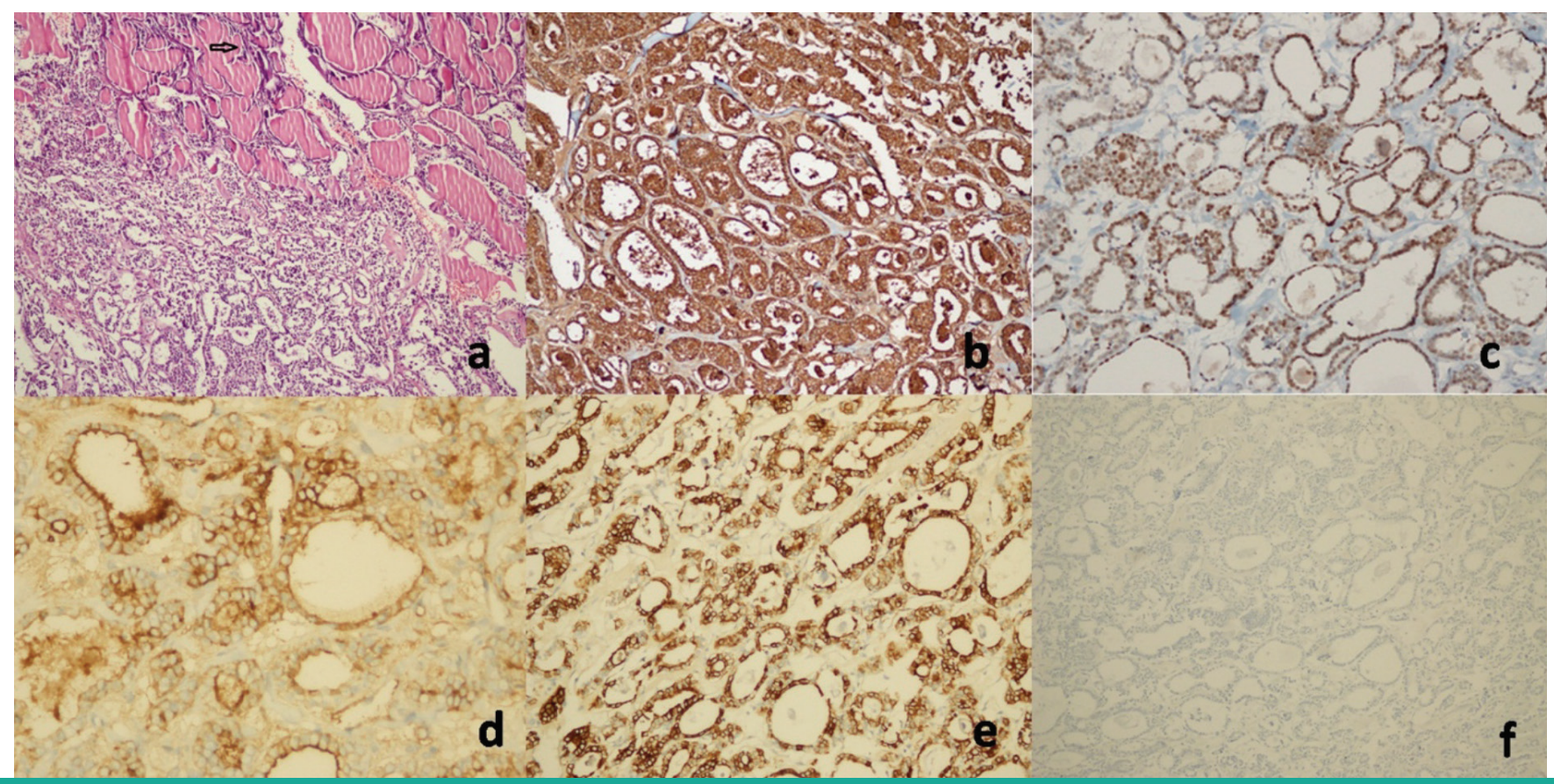

Figure 3. a) Spinal metastasis of the thyroid carcinoma, hematoxylin-eosin (HE) x10. The arrow indicated the tumor cells with colloidal appearance. b) Thyroglobuline (anti-Tg antibody, x10), c) TTF-1 (anti-TTF-1 antibody, x20), d) HBME-1 (antiHBME-1 antibody, x40), and e) CK-19 (anti-CK-19 antibody, x20) positivity, and f) calcitonin negativity 
Table 1: Characteristics of the patients and tumors

\begin{tabular}{|c|c|c|c|c|c|c|c|c|c|c|}
\hline No & Literature & $\begin{array}{l}\text { Age/ } \\
\text { gender }\end{array}$ & Level & $\begin{array}{l}\text { Neurologic } \\
\text { Finding }\end{array}$ & $\begin{array}{l}\text { Other } \\
\text { metastases }\end{array}$ & Surgery & $\begin{array}{l}\text { Thyroid } \\
\text { surgery }\end{array}$ & $\begin{array}{l}\text { Other } \\
\text { treatment }\end{array}$ & $\begin{array}{l}\text { FU } \\
\text { (mos) }\end{array}$ & Outcome \\
\hline 2 & Baiao (8) & $84 / F$ & T7-8-9 & Paraparesis $0 / 5$ & No & B & TT & RAI & 6 & Poor (ASIA B) \\
\hline 3 & Carhill (1) & $49 / F$ & $\mathrm{~S} 1$ & Pain & $\begin{array}{l}\text { Ilium, multiple } \\
\text { lung and liver }\end{array}$ & B & TT & RAI & 43 & Good (ASIA E) \\
\hline 4 & Chafiki (9) & $81 / F$ & L4-5-S1 & Paraparesis $0 / 5$ & No & B & TT & RAI & NM & NM \\
\hline 6 & Dong (10) & $48 / F$ & $\mathrm{C} 2-3$ & $\begin{array}{l}\text { Paresis of both } \\
\text { arms }\end{array}$ & C5, L1, S1, & $\mathrm{D}$ & TT & RAI & 52 & Good (ASIA E) \\
\hline 7 & Khan (11) & $35 / F$ & T11-12-L1 & Paraparesis $1 / 5$ & NM & D & NTT & RAI & 6 & Good (ASIA E) \\
\hline 8 & Kim (12) & $72 / \mathrm{M}$ & L4 & $\begin{array}{l}\text { Right big toe DF } \\
\text { weakness }\end{array}$ & No & TR & TT & RAI & 15 & Good (ASIA E) \\
\hline 11 & Okutan (14) & $33 / \mathrm{F}$ & L3 & Paraparesis $4 / 5$ & No & $\mathrm{TR} / \mathrm{St}$ & TT & RAI & NM & NM \\
\hline 12 & Sandu (15) & $50 / F$ & $\mathrm{~T} 11$ & Pain & $\begin{array}{l}\text { Multiple lung } \\
\text { nodules, L3, } \\
\text { ilium, femur }\end{array}$ & $\mathrm{D} / \mathrm{St}$ & TT & RAI & 45 & Good (ASIA E) \\
\hline 13 & Sharma (16) & $39 / \mathrm{M}$ & S1-2-3 & $\begin{array}{l}\text { Urinary } \\
\text { incontinence }\end{array}$ & No & B & TT & RT/RAI & 12 & Good \\
\hline 14 & Sharma (16) & $35 / F$ & $\mathrm{~T} 2-3$ & Paraparesis NM & No & $D$ & TT & $\mathrm{RT} / \mathrm{RAI}$ & 6 & NM \\
\hline 15 & Shibuya (17) & $67 / F$ & L4 & Pain & No & $\begin{array}{l}\text { B, D/St } \\
(2 y r s), D / S t \\
(5 y r s)\end{array}$ & TT & $\mathrm{RT} / \mathrm{RAI}$ & 66 & $\begin{array}{l}\text { Died/lung } \\
\text { metastases }\end{array}$ \\
\hline 20 & $\begin{array}{l}\text { Matsumoto } \\
\text { (21) }\end{array}$ & $48 / \mathrm{M}$ & T8 & Paraparesis $4 / 5$ & No & $\mathrm{TR} / \mathrm{St}$ & NM & NM & 156 & Good (ASIA E) \\
\hline 21 & $\begin{array}{l}\text { Matsumoto } \\
\text { (21) }\end{array}$ & $42 / M$ & T8-9-10 & Paraparesis $3 / 5$ & No & TR/St & NM & NM & 125 & Good (ASIA D) \\
\hline 22 & Scarrow (22) & $50 / \mathrm{M}$ & $\mathrm{C} 6$ & Pain & No & TR & TT & RAI & NM & NM \\
\hline 23 & Goldberg (23) & $65 / F$ & $\mathrm{C} 2$ & $\begin{array}{l}\text { Paresthesia on } \\
\text { one hand }\end{array}$ & No & TR & NTT & RAI & 28 & Good (ASIA E) \\
\hline 24 & Goldberg (23) & $43 / F$ & $\mathrm{~T} 1$ & Paraparesis & No & Biopsy & STT & $\mathrm{RT}$ & 7 & Ex \\
\hline 25 & Brodner (24) & $57 / \mathrm{M}$ & T5-6 & Paraparesis & No & TR & TT & RAI & 12 & Good (ASIA D) \\
\hline 26 & Brodner (24) & $56 / \mathrm{M}$ & $\mathrm{L} 2, \mathrm{C} 6$ & Paraparesis & No & No & TT & RAI & 214 & $\begin{array}{l}\text { Ex due to } \\
\text { leukemia }\end{array}$ \\
\hline 27 & Our patient & $45 / M$ & L2 & Pain & No & $\mathrm{TR} / \mathrm{St}$ & TT & RAI & 24 & Good (ASIA E) \\
\hline
\end{tabular}

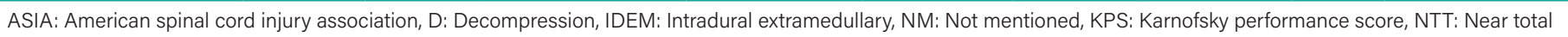
thyroidectomy, RAI: Radioactive iodine, St: Stabilization, STT: Subtotal thyroidectomy, TR: Total resection, TT: Total thyroidectomy 


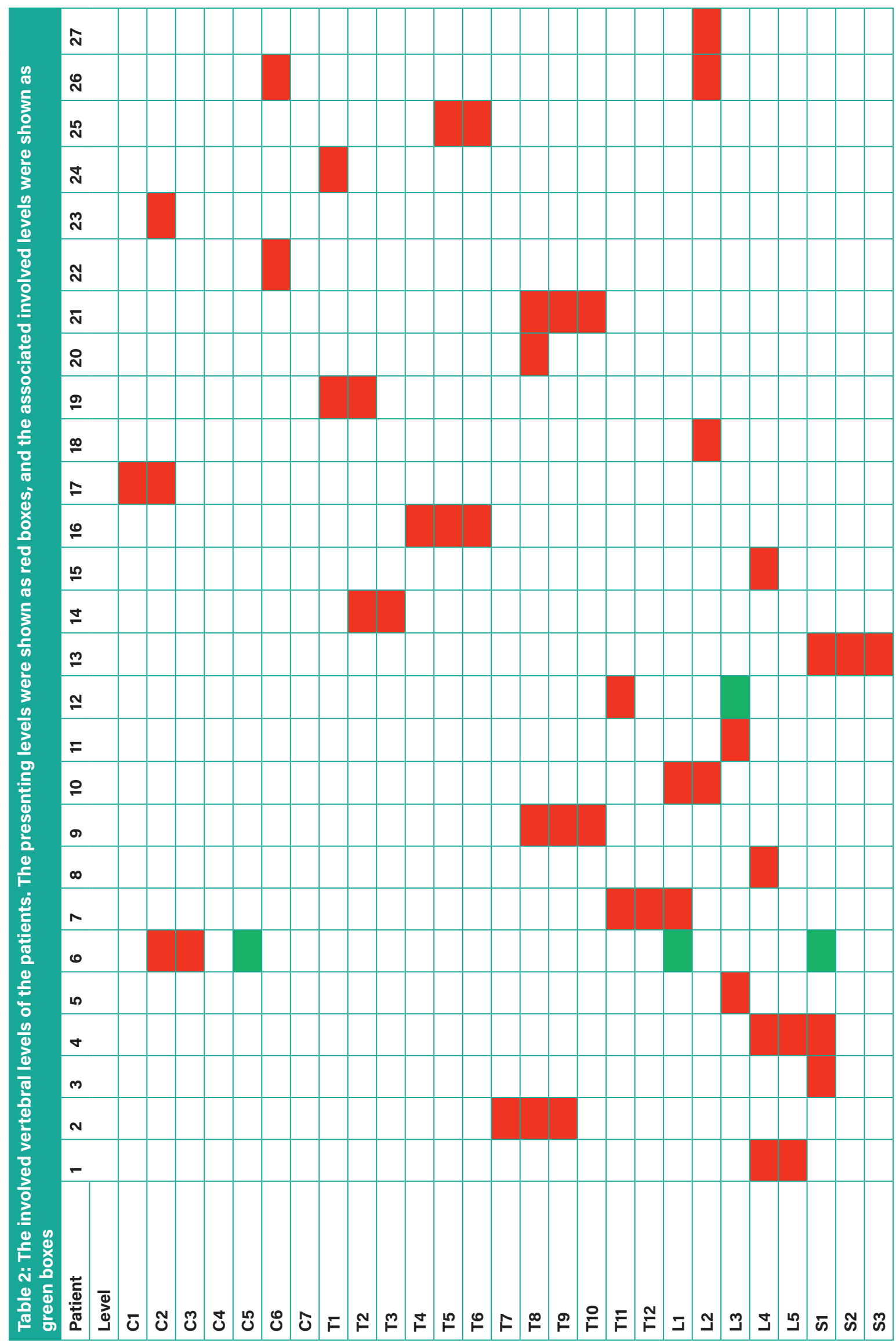


only 3 patients, there was multiple non-adjacent vertebral levels involvement. There were 5 patients with other bony metastases and/or systemic metastases such as lung or liver.

Nineteen patients were presented with paresis of arms and/or legs (9 of them could not mobilize without support), one with urinary incontinence and other 7 with back, neck, arm, or leg pain.

Various surgical modalities were performed in the patients. They could be classified as biopsy (in 7 cases), decompression with subtotal resection of the tumor (with or without stabilization, in 5 cases), and total resection of the tumor (with or without stabilization, in 14 cases). Any surgical procedure was not performed in one patient. Spinal stabilization was performed in total 10 patients during first surgery. In one patient in whom biopsy was performed first, subtotal resection and stabilization was performed in 2 times, 2 and 5 years after first biopsy.

Total or near total thyroidectomy was performed in 21 patients and subtotal thyroidectomy in one patient after spinal operation. Thyroid resection was not performed in 1 case and it was not mentioned in the article in 4 . In 2 cases, adjuvant treatment modalities were not mentioned in the articles, only radioactive iodine treatment (RAI) was performed in 17 cases, only radiotherapy (RT) for spinal lesions in 3 cases, and RAI and RT in combination in 5 cases.

The follow-up time was not mentioned in the articles in 4 cases. Other 23 cases were followed during 3 to 214 months $(43.7 \pm 53.2$, mean $\pm S D)$. Outcome was not mentioned for 3 patients. Three cases died due to systemic metastases of the disease 66, 36 and 7 months after their spinal surgeries, and one case died due to leukemia 214 months after diagnosis of the thyroid cancer. This last case was neurologically normal without systemic disease until development of his second neoplastic disease. Out of other 19 cases, 15 had good outcome with good neurological condition and without systemic disease (12 of them were neurologically normal), 3 cases had severe neurological deficits, and one case alive with systemic disease, but neurologically normal. Some patients who were severe neurological deficits before operation were neurologically normal on last follow-up $(11,13,21)$.

Presence of other distant metastases did not affect the last outcome $(\mathrm{p}=0.51)$. However, the type of the spinal surgery was found as an important factor on last outcome of the patient. The rate of good outcome was statistically higher in the patients performed total resection of the spinal metastasis than to be in the patients with only decompression or biopsy or without any surgical modality $(\mathrm{p}=0.027)$.

\section{Discussion}

Follicular type thyroid cancers constitute 15\% of the DTCs (1). They are well-differentiated tumors and have good outcome when they are compared with other cancers. However, bony metastasis is not rare in the cases with FTC (2). Rate of bony metastasis of FTC was reported as 7 to $20 \%$ and the rate of spinal metastasis as 1 to $7 \%(7,25)$. This characteristic is probably due to spreading ability via blood of FTC in contrary to the lymphatic spreading tendency of the papillary thyroid cancer $(1,2)$. FTC may synthesize some substrates providing attachment to bone matrix and promoting to bone reabsorbtion (1).

The FTC usually presents as tyhroid nodules. Presentation with distant metastases is quite rare, and it was reported in $1.9 \%$ to $11 \%$ of the cases with FTC $(6,26)$. Presentation with spinal cord compression due to spinal metastases is extremely rare. Pomorski and Bartos (6) reported only one case out of 309 FTC cases. We could only find 26 cases in literature and we added our case. In the series reported by Marcocci et al. (25), there were 18 patients whose presenting symptoms were related to bony metastases, however, it was not mentioned that how much of them were spinal metastases.

Survival of the DTCs is very long. It was reported that 10 year survival rate was about $80-95 \%$. However presence of bony distant metastases caused to decrease of this rate (12). Shaha et al. (26) reported that long-term survival in the cases with distant metastasis during initial presentation was quite high as $44 \%$. On the other hand, in spite of this long survival trend, presence of spinal metastases causes to reduce quality of life due to severe pain and/or neurological deficits (27). Coleman (28) reported in a retrospective study that spinal metastases of the DTCs more frequently cause spinal cord compression than other spinal metastases. Most of the cases reviewed in our study had neurological deficits and 10 of them could not mobilize on their admissions, and the patients without deficits had severe pain due to spinal metastases.

Reeve et al. (29) reported in a series consisting 258 cases with DTCs that age and gender were the most important factors affecting long-term outcome, and older patients ( $<60$ years) and males had significantly shorter survival. In our review, we could not perform survival analysis because most of the cases were still alive on their last follow-up. 
However, both age and gender of the cases did not affect the rate of good outcome.

Total resection of the spinal metastases of the DTCs is usually recommended because of their resistance to radiotherapy. Furthermore, spinal metastases of the DTCs are usually isolated metastases (27). In our review, also, there were associated other bony or systemic metastases in only 5 cases. Demura et al. (5) reported in a study evaluating the results of total en bloc spondylectomy for spinal metastases of thyroid carcinoma that there was no significant difference between the rate of long survival after total spondylectomy and debulking surgery, however, the rate of local recurrence was significantly higher in the cases treated with debulking surgery than the cases treated with total spondylectomy. In our review, the rate of good outcome was significantly higher in the patients whose spinal metastases were totally resected. However, in our study, the term of "total resection" was not similar to "total en bloc spondylectomy" in the study by Demura et al. (5) We classified total tumor resection only without total spondylectomy also as total resection. Response to RAI of DTC is very well, and the guidelines recommended adding this treatment modality to high risk group patients such as the ones with distant metastases (30). To add RAI into the treatment protocol may provide to take away the mandatory of total en bloc resection of the vertebrae with metastases.

Embolization of the spinal metastasis of DTCs before operation may be a smart choice because of tendency of these tumors to profuse bleeding (4). Sellin et al. (31) reported in a study evaluating the factors affecting survival of the patients with spinal metastases of thyroid carcinoma that preoperative emboliation was significantly associated with fewer complications. However, in the patients whose spinal metastases are the initial presentation, this choice can usually not be performed because the primary tumor is not known yet. In the patients presented with only pain without paresis, spinal biopsy may be performed and histological diagnosis can be provided before operation. However, emergency decompression may be required in some patients because of spinal cord or cauda compression, and there may not be adequate time for biopsy or embolization.

The Guideline of American Thyroid Association (ATA) reported in 2016 recommended resection of the lesion, stereotactic radiation treatment (RT) and RAI for treatment of central nervous system metastases of the DTCs (32). In our review, only 8 patients had received RT, therefore, we could not evaluate its efficacy on last outcome. Bernier et al. (33) recommended to perform total resection of bony metastases and RAI treatment instead of RT in the young patients ( $<45$ years) with bony metastases of the FTC.

Biochemical thyroid functional tests are usually in normal levels in the patients with thyroid cancers (13), therefore, routine tests usually do not provide diagnosis of thyroid cancer in the cases with spinal tumors, and some imaging tests such as thyroid ultrasonography are required during primary site screening. In the cases with cervical spinal tumors, cervical MRI can provide diagnosis of the primary thyroid tumors however most of the spinal metastases of the DTCs are located in the thoracic and lumbar levels. Therefore, if the more possible sites such as breast, lung or prostate are negative in the screening tests, thyroid screening with imaging modalities must certainly be added to the screening protocol of the spinal tumors. PET is also a very valuable method to show both primary site of the cancer and metastases (34).

Survival of the patients with spinal metastases due to DTCs is quite long. Sellin et al. (31) reported median 15.4 months in 43 cases, and Bernier et al. (33) reported 4.1 years. We could not evaluate the survival time of the patients in our review because most of them was still alive on their reported last follow up time. However, their follow up times were quite long $(43.7 \pm 53.2)$.

\section{Conclusion}

In conclusion, spinal metastasis as initial finding is very rare in the patients with FTC. However, this diagnosis must be kept in mind especially in the cases whose primary tumor site could not be found with routine cancer screening, and imaging modalities for thyroid must be added. Although survival of the patients with spinal metastases of FTC is significantly shorter than without spinal metastases, it is very longer than the patients with spinal metastases of other cancer types. Surgical resection of the spinal metastases especially in the patients with spinal cord or cauda equine compression, total/near total thyroidectomy and RAI treatment may provide a long term disease free survival to the patients.

\section{Ethics}

\section{Ethics Committee Approval: N/A.}

Informed Consent: N/A.

Peer-review: Externally peer-reviewed. 


\section{Authorship Contributions}

Surgical and Medical Practices: A.T., B.E., A.T., N.B., Concept: A.T., B.E., A.T., N.B., Ö.Y.A., İ.G., M.S.V., M.K., G.V., F.K.G., Design: A.T., B.E., A.T., N.B., Ö.Y.A., İ.G., M.S.V., M.K., F.K.G., Data Collection or Processing: A.T., B.E., A.T., Ö.Y.A., İ.G., M.S.V., M.K., G.V., F.K.G., Analysis or Interpretation: A.T., B.E., A.T., N.B., Ö.Y.A., İ.G., M.S.V., M.K., G.V., F.K.G., Literature Search: A.T., B.E., A.T., G.V., F.K.G., Writing: A.T., B.E., A.T., N.B., Ö.Y.A., İ.G., M.S.V., M.K., G.V., F.K.G.

Conflict of Interest: No conflict of interest was declared by the authors.

Financial Disclosure: The authors declared that this study received no financial support.

\section{References}

1. Carhill AA, Vassilopoulou-Sellin R. Durable effect of radioactive iodine in a patient with metastatic follicular thyroid carcinoma. Case Rep Endocrinol 2012;2012:231912.

2. McNeely MF, Sabath A, Linnau KF. Follicular thyroid carcinoma presenting as acute cord compression due to thoracic vertebral metastasis. Radiol Case Rep 2012;7:1-4.

3. Pacini F, Schlumberger M, Dralle H, Ilisea R, Smith Y, Viersinga V. European consensus for the management of patients with differentiated thyroid carcinoma of the follicular epithelium. Eur J Endocrinol 2006;154:787-803.

4. Chander A, Jayabalan V, Ganesan GR, Shanmugasundaram G, Kannan KK. Surgical management of follicular carcinoma of thyroid with spinal metastasis. International Surgery Journal 2015;2:599-603.

5. Demura S, Kawahara N, Murakami H, Abdel-Wanis ME, Kato S, Yohshioka K, Tomita K, Tsuchiya H. Total en-bloc spondylectomy for spinal metastases in thyroid carcinoma. J Neurosurg Spine 2011;14:172-176.

6. Pomorski L, Bartos M. Metastasis as the first sign of thyroid cancer. Neoplasma 1999;46:309-312.

7. Akhtar S, Adeel M. An unusual case of cauda equina secondary to spinal metastasis of thyroid cancer. Iranian J Otorhinolaryngol 2016;28:67-71.

8. Baiao JM, Guimaraes A, Moreira N, Correia JG, Rosevinge CU, Gonçalves D, Calvo MA. Acute paraparesis as presentation of an occult follicular thyroid carcinoma: A case report. Int J Surg Case Reports 2017;41:498-501.

9. Chafiki Z, Merzouki B, Hasnaoui J, Rouadi S, Abada R, Roubal M, Mahtar M. An occult follicular thyroid carcinoma revealed by an isolated cauda equina syndrome: a rare presentation. Glob J Otolaryngol 2017;3:1-4.

10. Dong P, Chen N, Li L, Huang R. An upper cervical cord compression secondary to occult follicular thyroid carcinoma metastases successfully treated with multiple radioiodine therapies. A clinical case report. Medicine 2017;96:e8215.

11. Khan MN, Sharfuzzaman A, Mostafa MG. Spinal cord compression as initial presentation of metastatic occult follicular thyroid carcinoma. J Neurosci Rural Pract 2014;5:155-159.
12. Kim DH, Yoo SD, Kim SM, Im SJ, Kang JK, Cho EH. Thyroid cancer initially presenting compression fracture without common thyroid symptoms. Ann Rehabil Med 2012;36:735-738.

13. Ogbodo E, Kaliaperumal C, Keohane C, Bermingham N, Kaar G. Sciatica as a presenting feature of thyroid follicular adenocarcinoma in a 79-year-old woman. BMJ Case Rep 2011;2011. pii: bcr1020115014.

14. Okutan O, Kaptanoglu E, Gocmen E, Solaroglu I, Beskonakli E, Koc M. Metastasis of follicular carcinoma of the thyroid to the lumbar vertebrae: A case report. Turkish Neurosurg 2005;15:32-35.

15. Sandu N, Pöpperl G, Toubert ME, Arasho B, Spiriev T, Orabi M, Schaller BJ. Molecular imaging of potential bone metastasis from differentiated thyroid cancer: a case report. J Med Case Rep 2011;5:522.

16. Sharma N, Purkayastha A. Follicular thyroid carcinoma presenting as large solitary vertebral metastasis: Report of two unusual cases treated with radiotherapy. Asia Pac J Oncol Nurs 2017;4:269-272.

17. Shibuya I, Sairyo K, Kanamori Y, Dezawa A. Four-Rod Stabilization of severely destabilized lumbar spine caused by metastatic tumor. Case Rep Orthop 2013;2013:254684.

18. Thoskezi G, Galgano MA, Libohova S, Marawar S. Isolated spinal metastasis with spinal cord compression leads to a diagnosis of a follicular thyroid carcinoma. Cureus 2015;7:e346.

19. Upreti V, Sridhar MS, Dhull P, Seri A. An unusual cause of progressive quadriparesis. Indian J Endocrinol Metab 2013;17(Suppl 1): S155-S156.

20. Hakeem AH. Spinal cord compression as initial presentation of follicular thyroid carcinoma Thyroid. Thyroid Disorders Ther 2014;3:3.

21. Matsumoto M, Tsuji T, Iwanami A, Watanabe K, Hosgane N, Ishii K, Nakamura M, Morioka H, Toyama Y. Total en bloc spondylectomy for spinal metastasis of differentiated thyroid cancers. A long-term follow-up. J Spinal Disord Tech 2013;26:E137-142.

22. Scarrow AM, Colina JL, Levy EI, Welch WC. Thyroid carcinoma with isolated spinal metastasis: case history and review of the literature. Clin Neurol Neurosurg 1999;101:245-248.

23. Goldberg H, Stein ME, Ben-Ithzak O, Duek D, Ravkin A, Gaitini D. Metastatic spinal cord compression as initial presentation of follicular thyroid carcinoma. J Surg Oncol 1998;67:186-189.

24. Brodner RA, Berman AJ, Wisniewski M, Nakagawa HK. Thyroid carcinoma presenting as epidural metastasis with spinal cord compression. Mt Sinai J Med (NY) 1975;42:207-215.

25. Marcocci C, Pacini F, Elisei R, Schipani E, Ceccarelli C, Miccoli P, Arganini M, Pinchera A. Clinical and biologic behavior of bone metastases fron differentiated thyroid carcinoma. Surgery 1989;106:960-966.

26. Shaha AR, Shah JP, Loree TR. Differentiated thyroid cancer presenting initially with distant metastasis. Am J Surg 1997;174:474-476.

27. Kushchayeva YS, Kushchayev SV, Wexler JA, Carroll NM, Preul MC, Teytelboym OM, Sonntag VK, Van Nostrand D, Burman KD, Boyle LM. Current treatment modalities for spinal metastases secondary to thyroid carcinoma. Thyroid 2014;24:1443-1455.

28. Coleman RE. Clinical features of metastatic bone disease and risk of skeletal morbidity. Clin Cancer Res 2006;12:6243-6249.

29. Reeve TS, Delbridge L, Crummer P. Total thyroidectomy in the management of differentiated thyroid cancer: a review of 258 cases. Aust N Z J Surg 1986;56:829-833. 
30. Uslu Besli L, Uslu I. Evaluation of response to therapy in thyroid carcinoma patients after radioactive iodine therapy. Bagcilar Medical Bulletin 2016;1:30-32.

31. Sellin JN, Suki D, Harsh V, Elder BD, Fahim DK, McCutcheon IE, Rao G, Rhines LD, Tatsui CE. Factors affecting survival in 43 consecutive patients after surgery for spinal metastases from thyroid carcinoma. J Neurosurg Spine 2015;23:419-428.

32. Haugen BR, Alexander EK, Bible KC, Doherty GM, Mandel SJ, Nikiforov YE, Pacini F, Randolph GW, Sawka AM, Schlumberger M, Schuff KG, Sherman SI, Sosa JA, Steward DL, Tuttle RM, Wartofsky L. 2015 American thyroid association management guidelines for adult patients with thyroid nodules and differentiated thyroid cancer: the American Thyroid Association (ATA) guidelines task force on thyroid nodules and differentiated thyroid cancer. Thyroid 2016;26:1-133.

33. Bernier MO, Leenhardt L, Hoang C, Aurengo A, Mary JY, Menegaux F, Enkaoua E, Turpin G, Chiras J, Saillant G, Hejblum G. Survival and therapeutic modalities in patients with bone metastases of differentiated thyroid carcinomas. J Clin Endocrinol Metab 2001;86:1568-1573.

34. Ramadan S, Ugas MA, Berwick RJ, Notay M, Cho H, Jerjes W, Giannoudis PV. Spinal metastasis in thyroid cancer. Head Neck Oncol 2012;4:39. 